\title{
Evaluation of various cultural enrichment methods for the detection of selected food borne bacterial pathogens
}

\author{
C. Latha, B. Sunil, V. J. Ajay Kumar, C. J. Anu and J. Deepa \\ Department of Veterinary Public Health \\ College of Veterinary and Animal Sciences, Kerala Veterinary and Animal Sciences University, Mannuthy, Kerala, India \\ Corresponding author: C. Latha, email: latha@kvasu.ac.in \\ Received: 01-01-2014, Revised: 27-02-2014, Accepted: 03-03-2014, Published online: 26-03-2014
}

doi: $10.14202 /$ vetworld.2014.172-176

How to cite this article: Latha C, Sunil B, Ajay Kumar VJ, Anu CJ and Deepa J (2014) Evaluation of various cultural enrichment methods for the detection of selected food borne bacterial pathogens, Veterinary World 7(3): 172-176.

\begin{abstract}
Aim: The study was conducted to evaluate the performance of different enrichment broths such as Tryptic Soy Yeast extract Broth (TSBYE), Brain Heart Infusion broth (BHI), Nutrient Broth (NB), Luria Broth (LB) and Peptone water (PW) for the detection of Listeria monocytogenes, Yersinia enterocolitica, Staphylococcus aureus and Salmonella enterica Typhimurium.
\end{abstract}

Materials and Methods: The bacterial strains were procured from Institute of Microbial Technology (IMTECH), Chandigarh. Growth of these food borne pathogens at two different incubation temperatures $\left(35^{\circ} \mathrm{C}\right.$ and $\left.37^{\circ} \mathrm{C}\right)$ and three different incubation periods (12h., 16h. and 18h.) were studied.

Results: The result of the study showed that enrichment in Tryptic soy broth with yeast extract (TSBYE) and incubation at $37^{\circ} \mathrm{C}$ for $18 \mathrm{~h}$. is superior for the enrichment of all the organisms under study.

Conclusion: TSBYE can be used very effectively as universal enrichment broth in comparison with all other enrichment broths studied for the detection of L. monocytogenes, Y. enterocolitica, S. aureus and S. enterica Typhimurium.

Keywords: broth, enrichment, foodborne pathogen, L. monocytogenes, S. aureus, S.enterica Typhimurium, Y. enterocolitica.

\section{I ntroduction}

Surveillance of food borne diseases is of utmost priority in the public health agenda worldwide. As per World Health Organization report [1] food borne diseases are responsible for high level of morbidity and mortality among the public. Listeria monocytogenes, Yersinia enterocolitica, Staphylococcus aureus and Salmonella enterica Typhimurium are agents of major concern because of their association with popular foods such as meat and meat products, dairy products, fruits and vegetables.

Listeria monocytogenes is an emerging food borne pathogen responsible for both sporadic and epidemic cases of Listeriosis associated with a variety of foods including meat products [2]. Listeria monocytogenes is responsible for the highest hospitalization rates (91\%) amongst all known food borne pathogens worldwide [3]. Yersinia enterocolitica is an important food and water borne pathogen causing a variety of gastrointestinal problems such as diarrhoea, abdominal pain and pseudo appendicitis $[4,5]$. There is a strong evidence that foods of animal origin especially pork and dairy products are responsible for $Y$. enterocolitica infections in humans [6].

Staphylococcus aureus is one of the most common agents of food poisoning outbreaks with enhanced pathogenicity due to the presence of enterotoxins [7,8]. According to CDC report [9], it is

Copyright: The authors. This article is an open access article licensed under the terms of the Creative Commons Attribution License (http://creativecommons.org/licenses/by/2.0) which permits unrestricted use, distribution and reproduction in any medium, provided the work is properly cited. responsible for 2,41,148 food borne illnesses worldwide. Contamination of food with staphylococci can occur directly from infected food producing animal or at any stages of food production, processing, transportation, storage or retailing [10]. Salmonellosis is recognized as a global zoonosis and food borne disease posing public health risk. It is the most widespread disease in both developed and developing countries and contributes to high morbidity and economic loss [11]. Salmonella infections have been associated with the consumption of raw and under cooked meat products [12].

Reliable detection techniques are a prerequisite for the detection of these pathogenic bacteria in food and food processing plants. Because the conventional culturing technique for detecting pathogens is time consuming, results are frequently not available until the food has been either released to the market or consumed, thus increasing the risk of transmission of pathogens [13].

Though sensitivity of many modern detection methods such as PCR have improved significantly, enrichment protocol is necessary to improve detection efficiency and to avoid false results because pathogens are often present in very low numbers in food samples rendering the recovery of target organisms difficult [14]. Development of multi pathogen detection in a single assay not only reduces the cost for testing but also provides data on the presence of different pathogens in a single experiment. Furthermore, multipathogen detection is a rational approach since many foods such as milk and milk products, meat and poultry, 
Table-1. Growth of selected bacterial food borne pathogens at various incubation temperatures after $18 \mathrm{~h}$ incubation in various broths

\begin{tabular}{|c|c|c|c|c|c|}
\hline \multirow{2}{*}{$\begin{array}{l}\text { Incubation } \\
\text { temperature }\end{array}$} & \multirow[t]{2}{*}{ Media } & \multicolumn{4}{|c|}{ Mean bacterial counts (Log10cfu/ml) \pm SE } \\
\hline & & L. monocytogenes & Y. enterocolitica & S. aureus & S. enterica Typhimurium \\
\hline \multirow[t]{5}{*}{$35^{\circ} \mathrm{C}$} & TSBYE & $9.3 \pm 0.04^{b}$ & $8.3 \pm 0.02^{\mathrm{bc}}$ & $9.27 \pm 0.08^{b}$ & $9.3 \pm 0.20^{\mathrm{cd}}$ \\
\hline & $\mathrm{BHI}$ & $8.3 \pm 0.03^{c}$ & $8.3 \pm 0.07^{b c}$ & $7.6 \pm 0.13^{\mathrm{cd}}$ & $8.4 \pm 0.14^{\mathrm{e}}$ \\
\hline & NB & $7.6 \pm 0.19^{\text {de }}$ & $7.8 \pm 0.08^{\mathrm{cd}}$ & $7.0 \pm 0.10^{d}$ & $8.3 \pm 0.09^{\mathrm{ef}}$ \\
\hline & LB & $7.4 \pm 0.12^{\mathrm{e}}$ & $7.3 \pm 0.02^{\text {de }}$ & $7.2 \pm 0.10^{d}$ & $8.1 \pm 0.03^{\mathrm{ef}}$ \\
\hline & PW & $6.7 \pm 0.16^{\dagger}$ & $6.9 \pm 0.04^{\mathrm{e}}$ & $7.1 \pm 0.08^{d}$ & $7.8 \pm 0.25^{f}$ \\
\hline \multirow[t]{5}{*}{$37^{\circ} \mathrm{C}$} & TSBYE & $10.3 \pm 0.27^{\mathrm{a}}$ & $9.5 \pm 0.20^{\mathrm{a}}$ & $11.0 \pm 0.21^{\mathrm{a}}$ & $10.4 \pm 0.14^{\mathrm{a}}$ \\
\hline & $\mathrm{BHI}$ & $8.6 \pm 0.20^{b c}$ & $8.6 \pm 0.40^{b}$ & $9.2 \pm 0.08^{b}$ & $10.1 \pm 0.06^{\mathrm{ab}}$ \\
\hline & NB & $8.3 \pm 0.22^{c}$ & $8.2 \pm 0.27^{\mathrm{bc}}$ & $8.9 \pm 0.36^{b}$ & $9.7 \pm 0.39^{b c}$ \\
\hline & LB & $8.2 \pm 0.46^{\mathrm{cd}}$ & $7.8 \pm 0.36^{\mathrm{cd}}$ & $7.9 \pm .36^{c}$ & $8.1 \pm 0.09^{\mathrm{ef}}$ \\
\hline & PW & $6.6 \pm 0.22^{f}$ & $7.7 \pm 0.37^{\mathrm{cd}}$ & $8.1 \pm 0.11^{c}$ & $8.9 \pm 0.19^{d}$ \\
\hline
\end{tabular}

Values with different superscripts in the same column differ significantly, $p<0.05$.

fruits and vegetables are common carriers of these food borne pathogens [15]. Hence, the present study was carried out to evaluate different enrichment techniques for the isolation of L. monocytogenes, Y. enterocolitica, $S$. aureus and S. enterica Typhimurium.

\section{Materials and Methods}

Bacterial strains: The reference strains of bacterial pathogens, L. monocytogenes (MTCC 1143), $Y$. enterocolitica (MTCC 3234), S. aureus (MTCC 1144) and S. enterica Typhimurium (MTCC 98) were procured from Microbial type culture collection and Gene bank (MTCC), Institute of Microbial Technology (IMTECH), Chandigarh. Maintenance of pure cultures was carried out by regular sub culturing onto Nutrient Agar slants at 25 days interval.

Comparison of different enrichment methods for isolation: Five different enrichment broths including Tryptic Soy Yeast extract Broth (TSBYE), Brain Heart Infusion broth (BHI), Nutrient Broth (NB), Luria Broth (LB) and Peptone water (PW), were used for the isolation of L. monocytogenes, Y. enterocolitica, S. aureus and $S$. enterica Typhimurium, respectively. A loopful of individual bacterial culture was inoculated into five different broths. Two different incubation temperatures $\left(35^{\circ} \mathrm{C}\right.$ and $\left.37^{\circ} \mathrm{C}\right)$ and three different incubation time (12h., 16h. and 18h.) were studied. The inoculated tubes were incubated at different incubation conditions. Duplicate tubes were used for each enrichment condition. After the period of incubation, optical density (OD) was measured using spectrophotometer at 600nm (Perkin Elmer, Lambda 25).

I solation and tdentification of organisms: For the isolation and identification of organisms, serial dilution was made and selected dilutions were plated onto selective agar plates. For the isolation of $L$. monocytogenes, $0.1 \mathrm{ml}$ of inoculum from selected dilution was transferred to Polymyxin- AcriflavinLithium Chloride- Ceftazidime- Aesculin- Mannitol (PALCAM) agar plates and incubated at $37^{\circ} \mathrm{C}$ for $48 \mathrm{~h}$. After incubation, colonies with graygreen colour with a sunken centre and halo were counted. Yersinia identi- fication agar was used for the isolation of $Y$. enterocolitica. After incubation at $37^{\circ} \mathrm{C}$ for $24 \mathrm{~h}$., red bull's eye colonies were counted. For the isolation of S.aureus, Baird Parker (BP) agar plates were used and incubated at $37^{\circ} \mathrm{C}$ for $48 \mathrm{~h}$. After incubation, grey black to jet black colonies with light coloured margin surrounded by an opaque zone were counted. From selected dilution, $0.1 \mathrm{ml}$ of the inoculum was transferred to Brilliant Green Sulpha agar plates for isolating $S$. enterica Typhimurium and incubated at $37^{\circ} \mathrm{C}$ for $24 \mathrm{~h}$. After incubation, pink coloured colonies were counted [16]. Selected colonies were then subjected to a series of biochemical tests for confirmation. The entire protocol was repeated for six times.

Statistical analysis: All data were analysed by ANOVA and Duncan's multiple range test (DMRT) using SPSS, Version 22.0.

\section{Results}

The growth of individual organisms in different broths at different incubation conditions were analyzed after the period of incubation. The optical density was measured using Spectrophotometer at 600nm. The counts obtained against each OD values were compared as per McFarland Standards [17].

The mean OD values of different organisms after incubation at $12 \mathrm{~h} ., 16 \mathrm{~h}$. and $18 \mathrm{~h}$. are given in Figures 14. Repeated measures two factor ANOVA was carried out for comparing OD values of different broths in different periods at $37^{\circ} \mathrm{C}$. Results showed that the OD values of different broths significantly increased from $12 \mathrm{~h}$. to $18 \mathrm{~h}$ ( $\mathrm{p} \leq 0.01)$. A highly significant difference was observed in OD values between all enrichment broths and enrichment conditions $(\mathrm{p} \leq 0.01)$.

The mean counts of individual organisms at two different incubation temperatures, viz. $35^{\circ} \mathrm{C}$ and $37^{\circ} \mathrm{C}$ are shown in Table-1. Lowest mean count was observed for all organisms at $35^{\circ} \mathrm{C}$ in PW except for $S$. aureus. At $37^{\circ} \mathrm{C}$, lowest count was observed for $L$. monocytogenes and Y. enterocolitica in PW and in LB for $S$. aureus and $S$. enterica Typhimurium.

A significant difference in mean count was found 


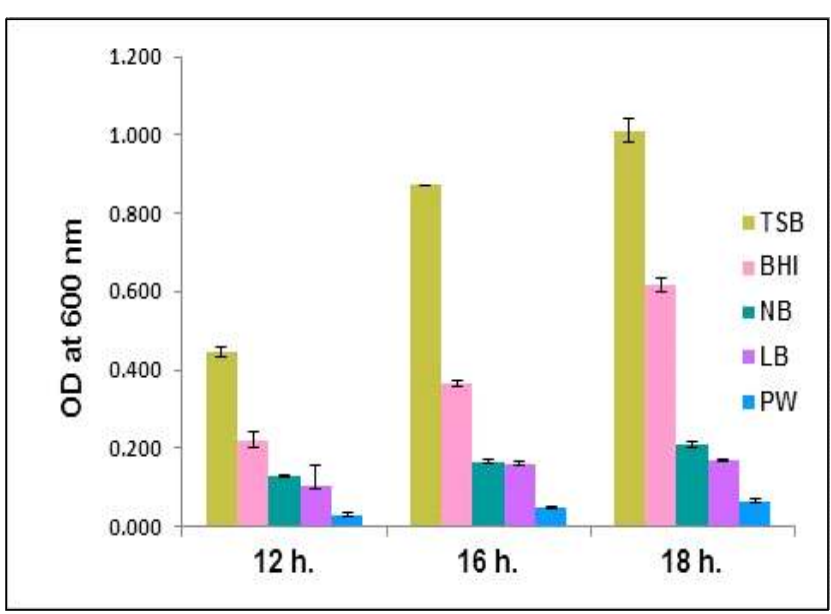

Figure-1: OD values of L. monocytogenes in different broths

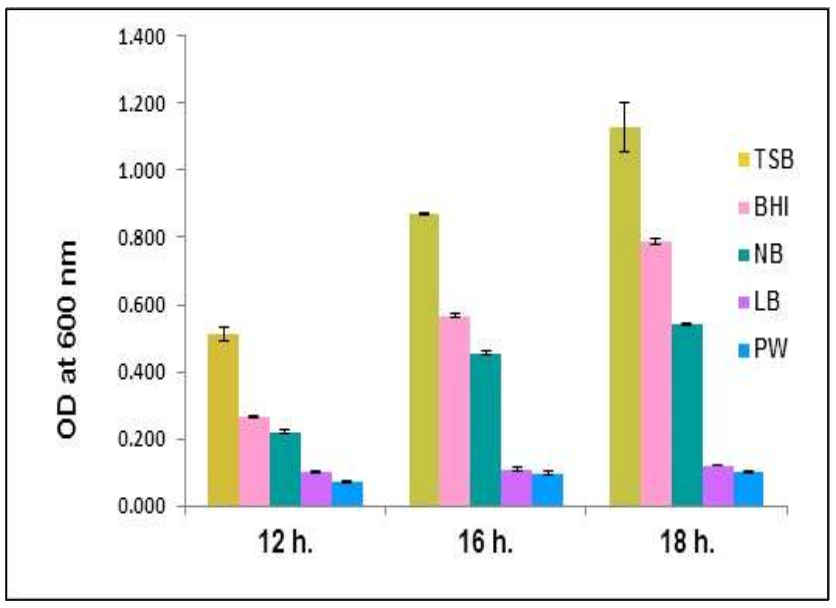

Figure-3: OD values of S. aureus in different broths

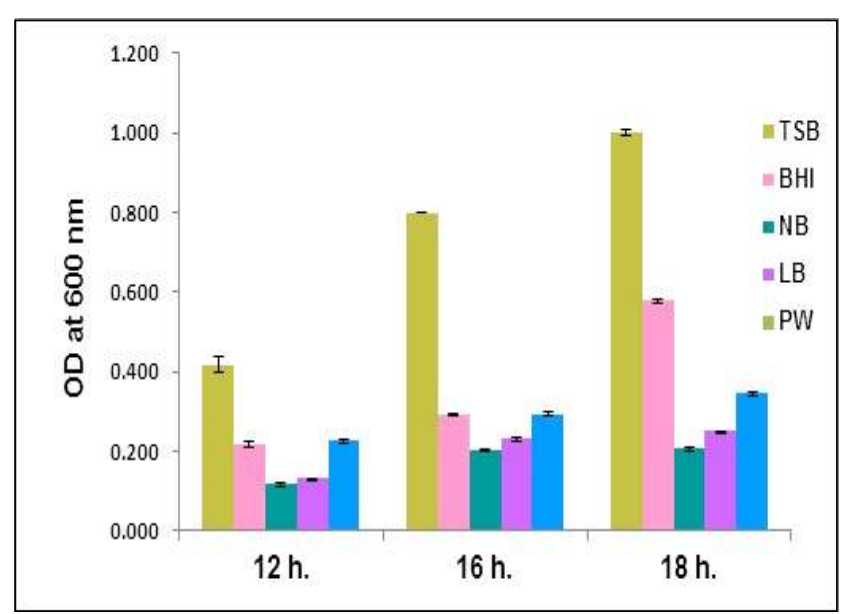

Figure-2: OD values of $Y$. enterocolitica in different broths

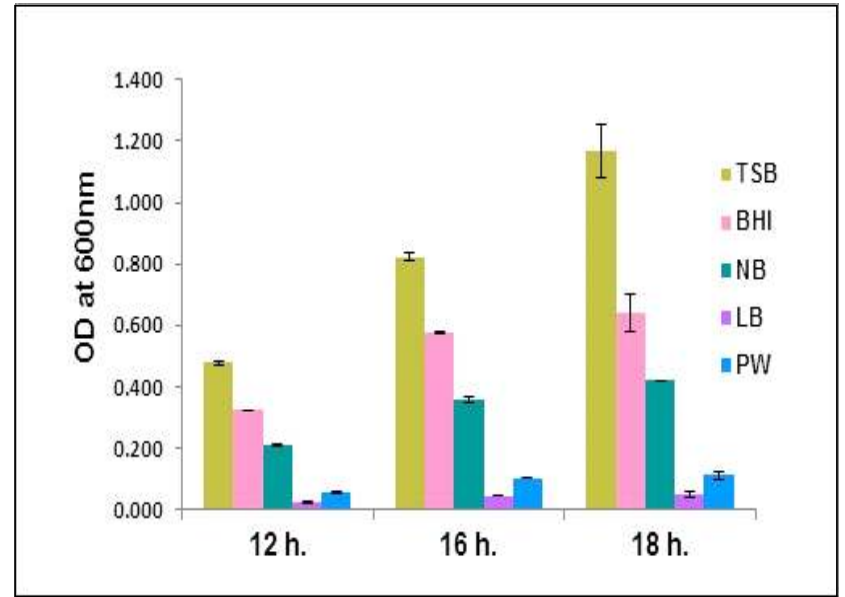

Figure-4: OD values of S. enterica Typhimurium in different broths

Table-2. Growth of different organisms at different incubation periods at $37^{\circ} \mathrm{C}$ update as before

\begin{tabular}{|c|c|c|c|c|c|}
\hline \multirow{2}{*}{$\begin{array}{l}\text { Incubation } \\
\text { time }\end{array}$} & \multirow[t]{2}{*}{ Media } & \multicolumn{4}{|c|}{ Mean bacterial counts $(\log 10 \mathrm{cfu} / \mathrm{ml}) \pm \mathrm{SE}$} \\
\hline & & L. monocytogenes & Y. enterocolitica & S. aureus & S. enterica Typhimurium \\
\hline \multirow[t]{5}{*}{$12 \mathrm{~h}}$. & TSBYE & $6.89 \pm 0.29^{\mathrm{de}}$ & $6.49 \pm 0.02^{\text {fg }}$ & $7.069 \pm 0.03^{f}$ & $6.85 \pm 0.05^{9}$ \\
\hline & $\mathrm{BHI}$ & $6.40 \pm 0.19^{\text {ef }}$ & $5.99 \pm 0.06^{\text {gh }}$ & $6.82 \pm 0.11^{\dagger}$ & $6.46 \pm 0.02^{j}$ \\
\hline & NB & $5.93 \pm 0.33^{\mathrm{fg}}$ & $5.80 \pm 0.16^{\mathrm{h}}$ & $4.57 \pm 0.16^{\mathrm{h}}$ & $5.89 \pm 0.03^{k}$ \\
\hline & LB & $5.69 \pm 0.26^{9}$ & $5.35 \pm 0.13^{h}$ & $6.64 \pm 0.14^{\dagger}$ & $5.73 \pm 0.22^{k}$ \\
\hline & PW & $5.29 \pm 0.09^{g}$ & $5.80 \pm 0.12^{h}$ & $5.21 \pm 0.10^{9}$ & $5.4 \pm 0.32^{1}$ \\
\hline \multirow[t]{5}{*}{$16 \mathrm{~h}}$. & TSBYE & $9.17 \pm 0.11^{b}$ & $8.17 \pm 0.06^{\mathrm{c}}$ & $9.26 \pm 0.10^{b}$ & $9.26 \pm 0.07^{d}$ \\
\hline & $\mathrm{BHI}$ & $8.60 \pm 0.17^{\text {bc }}$ & $6.88 \pm 0.14^{\text {ef }}$ & $8.64 \pm 0.17^{\mathrm{c}}$ & $8.80 \pm 0.02^{e}$ \\
\hline & NB & $8.40 \pm 0.19^{c}$ & $7.41 \pm 0.22^{\mathrm{de}}$ & $7.83 \pm 0.27^{\mathrm{e}}$ & $8.39 \pm 0.08^{f}$ \\
\hline & LB & $7.32 \pm 0.07^{d}$ & $6.65 \pm 0.37^{f}$ & $7.89 \pm 0.24^{e}$ & $7.34 \pm 0.18^{h}$ \\
\hline & PW & $6.73 \pm 0.10^{\mathrm{de}}$ & $7.02 \pm 0.24^{\text {ef }}$ & $5.98 \pm 0.14^{\dagger}$ & $6.77 \pm 0.14^{i}$ \\
\hline \multirow[t]{5}{*}{$18 \mathrm{~h}}$. & TSBYE & $10.03 \pm 0.18^{\mathrm{a}}$ & $9.28 \pm 0.1^{\mathrm{a}}$ & $11.09 \pm 0.20^{\mathrm{a}}$ & $10.37 \pm 0.08^{\mathrm{a}}$ \\
\hline & $\mathrm{BHI}$ & $8.87 \pm 0.07^{b c}$ & $8.93 \pm 0.33^{\mathrm{ab}}$ & $9.37 \pm 0.16^{b}$ & $10.01 \pm 0.2^{b}$ \\
\hline & NB & $8.42 \pm 0.19^{c}$ & $8.51 \pm 0.17^{b c}$ & $8.57 \pm 0.15^{c d}$ & $9.71 \pm 0.15^{c}$ \\
\hline & LB & $8.29 \pm 0.46^{c}$ & $8.12 \pm 0.30^{c}$ & $8.05 \pm 0.19^{\mathrm{e}}$ & $8.16 \pm 0.05^{9}$ \\
\hline & PW & $6.89 \pm 0.11^{\mathrm{de}}$ & $7.87 \pm 0.30^{\text {cd }}$ & $8.16 \pm 0.05^{\mathrm{de}}$ & $8.72 \pm 0.15^{\mathrm{e}}$ \\
\hline
\end{tabular}

Values with different superscripts in the same column differ significantly, $p<0.05$.

between TSBYE and all other enrichment broths for $L$. monocytogenes, $S$. aureus and $S$. enterica Typhimurium at $35^{\circ} \mathrm{C}$, but the bacterial counts in BHI, LB, NB and PW did not differ significantly except for L. monocytogenes. At $37^{\circ} \mathrm{C}$, no significant difference was found between all the counts in NB and BHI. All the organisms had maximum bacterial counts in
TSBYE and showed significant difference from BHI except for $S$. enterica Typhimurium. Among the different temperatures studied, incubation at $37^{\circ} \mathrm{C}$ showed better results than $35^{\circ} \mathrm{C}$ and so, $37^{\circ} \mathrm{C}$ was selected as the incubation temperature for further study.

Table- 2 represents the growth of different organi- 
sms at different incubation periods viz. $12 \mathrm{~h}$., $16 \mathrm{~h}$. and $18 \mathrm{~h}$.at $37^{\circ} \mathrm{C}$. At $16 \mathrm{~h}$. lowest count was observed for $L$. monocytogenes, S. aureus and S. enterica Typhimurium in PW and in LB for $Y$. enterocolitica. Highest bacterial count was found in TSBYE followed by BHI and NB after $18 \mathrm{~h}$. of incubation.

The results showed that variation in bacterial counts significantly increased from $12 \mathrm{~h}$. to $18 \mathrm{~h}$. After $12 \mathrm{~h}$. incubation, mean counts of L. monocytogenes and $Y$. enterocolitica in different enrichment broths did not show any significant difference. Whereas at $18 \mathrm{~h}$. of incubation significant difference was found between TSBYE and other enrichment broths except for $Y$. enterocolitica.

\section{Discussion}

The study revealed that the TSBYE supported the growth of the four pathogens significantly within $18 \mathrm{~h}$. at $37^{\circ} \mathrm{C}$ compared to the other enrichment broths used in the study.The use of TSBYE has a number of advantages over individual selective media used for the isolation of each pathogen in the study. Selective media are often inhibitory and fail to recover cells which may have been injured during food preservation processes [18]. In addition, some of the selective agents are expensive and toxic [19]. However, TSBYE is more economical and easy to handle as an enrichment media.

The ability of TSB in the recovery of $L$. monocytogenes, Y.enterocolitica, S. aureus and $S$. enterica Typhimurium has been reported by many workers. Kim and Bhunia [14] developed an enrichment broth (SEL) containing Tryptic soy broth, yeast extract and antimicrobial agents which are proven to support the growth of healthy and injured foodborne pathogens. The recovery of $L$. monocytogenes in TSBYE was reported by Amoako et al [20]. The present study revealed that TSBYE produced two fold higher cell density for $L$. monocytogenes after $18 \mathrm{~h}$. incubation at $37^{\circ} \mathrm{C}$ compared to BHI followed by NB and LB. A fourfold difference was found between TSBYE and PW for the growth of the organism. Singh and Virdi [21] used TSB for the semi selective enrichment of $Y$. enterocolitica. Balakrishna et al. [22] also reported the use of TSB for the growth of $Y$. enterocolitica. In the study, growth of $Y$. enterocolitica in TSBYE was found significantly different from BHI, NB, LB and PW.

In the present study, a one fold significant increase in cell count was found for $S$. aureus in TSBYE compared to NB, which was in agreement with the report by Bocher et al. [23] who stated that the sensitivity of TSB was significantly higher compared to NB for the growth of Methicillin resistant $S$. aureus. In another study, Khueankhancharoen and Thipayarat [24] studied the growth kinetics of salmonella in different traditional enrichment broths such as NB, LB, BPW and TSB and reported that TSB was superior to LB and NB for the isolation of S. enterica Typhimurium. The log scale increase from the initial count to $5 \mathrm{log}$ $\mathrm{cfu} / \mathrm{ml}$ was achieved within $10 \mathrm{~h}$. while in the present study, an increase of $10 \mathrm{log} \mathrm{cfu} / \mathrm{ml}$ was achieved in TSBYE within $18 \mathrm{~h}$.

\section{Conclusion}

It is evident from this study that TSBYE promoted the growth of four major food borne pathogens, $L$. monocytogenes, $Y$. enterocolitica, $S$. aureus and $S$. enterica Typhimurium, significantly. Based on the data obtained in this study, TSBYE can be used very effectively as universal enrichment broth in comparison with all other enrichment broths studied for the detection of these food-borne pathogens by all techniques including cultural and molecular methods.

\section{Authors' contributions}

CL designed the study and initiated the research. VJA and CJA carried out collection of samples, standardisation of procedure, draft and revision of manuscript. BS and JD helped in interpretation of results. All authors read and approved the final manuscript.

\section{Acknowledgements}

Kerala State Council for Science Technology and Environment, India is duly acknowledged for the financial support extended for this work.

\section{Competing interests}

The authors declare that they have no competing interests.

\section{References}

1. WHO. (2013) Report on food borne disease surveillance. http://www.who.Int/foodborne _ disease/en/html. Accessed 05-12-2013.

2. Sunil, B., Latha, C., Remya, R., Ajaykumar, V.J. and Vrinda Menon, K. (2012) Comparison of different enrichment methods for the detection of L.monocytogenes from milk samples. J. Ind. Vet. Assoc., Kerala. 10 (2):20-21.

3. Jemmi, C.T. and Stephan, R. (2006) L. monocytogenes: Food borne pathogen and Hygiene indicator. Rev. Sci. Tech .Eff. Int. Epiz. 25(2):571-580.

4. Bottone, E.J. (1999) Yersinia enterocolitica: Overview and epidemiologic correlates. Microbes Infect. 1:323-333.

5. Boghenbor, K.K., Stephen, L.W.O., Branko, K., Andreas, B., Trudy, M.W., Matthias, W., Beatrice, B.C. and Joachim, F. (2006) Genotyping of Human and Porcine Y. enterocolitica, $Y$. intermedia and $Y$. bercovieri strains from Switzerland by Amplified Fragment Length Polymorphism analysis. Appl. Environ. Microbiol. 72 (6): 4061-4066.

6. Kwaga, J. and Iversen, J.O. (1992) Laboratory investigation of virulence among strains of Yersinia enterocolitica and related species isolated from pigs and pork products. Can.J. Microbiol. 38: 92-97.

7. Pelliser, M.R., Klein, C.S., Ascoli, K.R., Zotti, T.R., Arisil, A.C.M. (2009) Occurrence of Staphylococcus aureus and multiplex PCR detection of classic enterotoxin genes in cheese and meat products. Braz. J. Microbiol. 40: 145-148.

8. Akineden, O., Hassan, A.A., Schneider, E., Usleber, E. (2008) Enterotoxigenic properties of Staphylococcus aureus isolated from goat's milk cheese. Int. J. Food Microbiol. 124: 211-216.

9. CDC. (2011) CDC estimates of food borne illness in United States. http://www.cdc.gov/foodborneburden/2011foodborne-estimates.html. Accessed on 21-11-2013.

10. Normanno, G., La Salandra, G., Dambrosio, A., Quaglia, N.C., Corrente, M., Parisi, A., Santagada, G., Firinu, A., Crisetti, E., Celano, G.V. (2007) Occurrence, Characteri- 
zation and antimicrobial resistance of enterotoxigenic Staphylococcus aureus isolated from meat and Dairy products. Int. J. Food Microbiol. 115: 290-296.

11. Antoine, S.T., Annaelle, K., Anne, B. (2008) Epidemiological analysis ofSalmonella enterica from beef sampled in the slaughter house and retailersin Dakar (Senegal) using pulsed field gel electrophoresis and antibiotic susceptibility testing. J. Food Microbiol. 123:191197.

12. Robles, G.M., Loredo, A., Ojeda, G., Vega, A., Chew, Y., Velarde, S., Fratamico, P. (2008) Identification of Salmonella serovars isolated from Cantaloupe and Chile pepper production systems in Mexico by PCR-RFLP. J. Food Protect.71 (11): 2217-2222.

13. Kawasaki, S., Fratamico, P.M., Horikoshi, N., Okada, Y., Takeshita, K., Sameshima, T. and Kawamoto, S. (2009) Evaluation of a multiplex PCR system for simultaneous detection of Salmonella, E.coli O157:H7, and L. monocytogenes in foods and in food subjected to freezing. Foodborne Path. Dis. 6(1):81-88.

14. Gracias, K. S., and Mc Killip, J. L. (2004) A review of conventional detection and enumeration methods for pathogenic bacteria in food. Can. J. Microbiol. 50:883-890.

15. Kim, H. and Bhunia, A.K. (2008) SEL, a selective enrichment broth for simultaneous growth of Salmonella enterica, E. coli O157:H7, and L.monocytogenes. Appl. Environ. Microbiol.74(15): 4853-4866.

16. APHA. (2001) Compendium of methods for the Microbiological examination of foods ( $4^{\text {the }}$ ed.) Washington DC, pp 343-428.

17. Mcfarland, J. (1907) The nephelometer: An instrument for estimating the number of bacteria in suspensions used for calculating the opsonic index and for vaccines. J. Am. Med.
Assoc. 14:1176-1178.

18. Busch, S.V., Donnelly, C.W. (1992) Development of a repair enrichment broth for the resuscitation of heat injured $L$. monocytogenes and L.innocua. Appl. Environ. Microbiol. 58(1): 14-20.

19. Cloak, O.M., Duffy, G., Sheridan, J.J., Blair, I.S., Mc Dowell, D.A. (1999) Isolation and detection of Listeria spp, Salmonella spp and Yersinia spp using a simultaneous enrichment step followed by a surface adhesion immune fluorescent technique. J. Microbiol. Methods. 39(1): 33-43.

20. Amoako, E.B., Syed, T., Richard, F.A. and Jim, S. (1992) Evaluation of the ability of primary selective enrichment to resuscitate heat-injured and freeze-injured Listeria monocytogenes cells. Appl. Environ. Microbiol. 58(9): 31773179 .

21. Singh, I and Virdi, J.S. (2011) Production of Yersiniastable toxin (YST) and distribution of ystgenes in biotype 1A strains of Yersinia enterocolitica. J. Med. Microbiol. 53:1065-1068.

22. Balakrishna, K., Murali, H.S., Batra, H.V. (2010) Cloning, expression and characterization of attachment invasion locus protein (ail) of $Y$. enterocolitica and its utilization in rapid detection by immunoassays. Letters Appl. Microbiol. 50: 131-137.

23. Bocher, S.B., Middendorf, H., Westh, A., Mellmann, K., Becker, R., Skov, R. and Friedrich, A.W. (2010) Semiselective broth improves screening for methicillin-resistant Staphylococcus aureus.J. Antimicrob. Chemother. 65: 717720 .

24. Khueankhancharoen, J and Thipayarat, A. (2011) Application of modified drop plate technique (MDPT) and logistic model to optimize non-selective substrates for Salmonella typhi resuscitation. Asian. J. Food Ag-Ind. 4(06): 349-358. 